DOE/ID-10739 (2001)

February 2002

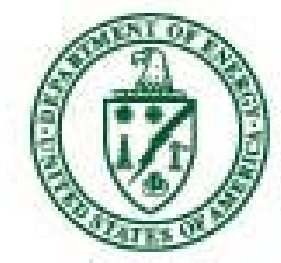

U.S. Department of Energy Idaho Operations Office

\title{
Annual Radiological Environmental Monitoring Program Report for the Three Mile Island, Unit 2, Independent Spent Fuel Storage Installation
}




\title{
Annual Radiological Environmental Monitoring Program Report for the Three Mile Island, Unit 2, Independent Spent Fuel Storage Installation
}

\author{
G. G. Hall, CHP REM
}

Published February 2002

Idaho National Engineering and Environmental Laboratory Idaho Nuclear Technology and Engineering Center Idaho Falls, Idaho 83415

Prepared for the U. S. Department of Energy

Assistant Secretary for Environmental Management Under DOE Idaho Operations Office

Contract DE-AC07-99ID13727 


\begin{abstract}
This report presents the results of the 2001 Radiological Environmental Monitoring Program conducted in accordance with 10 CFR 72.44 for the Three Mile Island, Unit 2, Independent Spent Fuel Storage Installation. A description of the facility and the monitoring program is provided. The results of monitoring the two predominant radiation exposure pathways, potential airborne radioactivity releases and direct radiation exposure, indicate the facility operation has not contributed to any increase in the estimated maximum potential dose commitment to the general public.
\end{abstract}




\section{SUMMARY}

The purpose of this report is to present the results of the Radiological Environmental Monitoring Program (REMP) conducted during 2001 for the Three Mile Island, Unit 2, (TMI-2), Independent Spent Fuel Storage Installation (ISFSI). The first shipment of TMI-2 core debris was received and stored at the ISFSI on March 31, 1999. Nine additional shipments were received and stored at the ISFSI during 2000. The remaining nineteen shipments were received during 2001 and completed on April 20, 2001.

The REMP was implemented from January through December 2001. Results of the loose surface radioactive contamination surveys indicated no increase in either gross beta or Cs-137 radioactivity attributed to the facility operation. The results of the airborne radioactivity sampling did not indicate releases of airborne particulate radioactivity from the loaded Horizontal Storage Modules (HSM). The results of the thermoluminescent dosimetry network did not indicate an increase in radiation levels above ambient background attributed to the facility operation.

The monitoring program results support the conclusion reached in the Final Environmental Impact Statement that operation of the facility would not result in a significant dose commitment to the Maximum Exposed Individual. 


\section{CONTENTS}

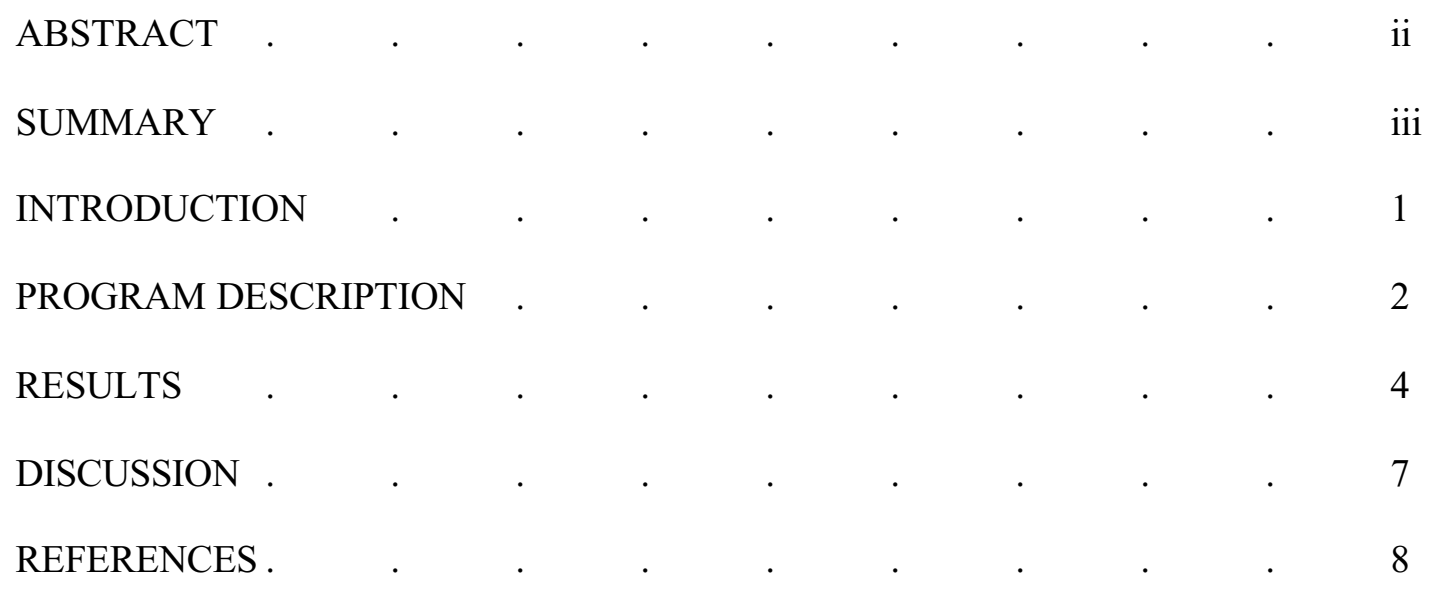

\section{FIGURES}

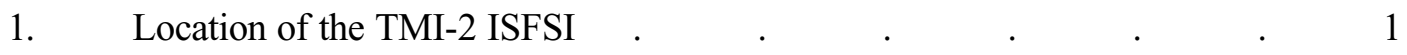

2. TMI-2 ISFSI TLD Station Locations $\quad . \quad$. $\quad . \quad$. $\quad$. 3

\section{TABLES}

1. TMI-2 Core Debris Storage Status . . . . $\quad$. 2

2. Highest Detected Radiation Summary for Loaded HSM's (mrem/h) . 4

3. TMI-2 ISFSI Port Survey Gross Beta/Alpha Results $\left(\mathrm{dpm} / 100 \mathrm{~cm}^{2}\right) \quad$. 5

4. TMI-2 ISFSI Purge, Vent, and Drain Port Survey Gamma Isotopic Results

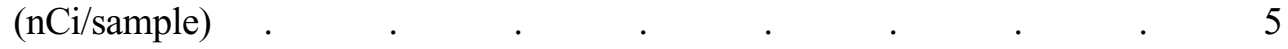

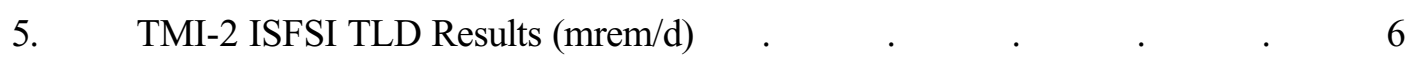

6. TMI-2 ISFSI Air Sample Results $\left(\mathrm{pCi} / \mathrm{m}^{3}\right) \quad \ldots \quad \ldots \quad$. $\quad . \quad 7$

7. Postulated Airborne Radioactive Material Release During Normal Operations

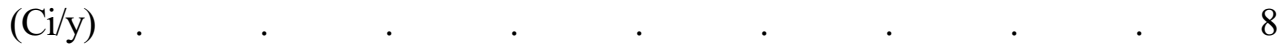

8. Gamma Spectroscopy Intercomparison Results for June and December 2001 $(\mathrm{Bq} /$ filter) 


\section{Annual Radiological Environmental Monitoring Program Report for the Three Mile Island, Unit 2, Independent Spent Fuel Storage Installation}

\section{INTRODUCTION}

The Three Mile Island, Unit 2, Independent Spent Fuel Storage Installation (TMI-2 ISFSI) is a spent fuel dry storage facility designed for interim storage of the TMI-2 core debris. The TMI-2 ISFSI, located within the Idaho Nuclear Technology and Engineering Center (INTEC) at the Idaho National Engineering and Environmental Laboratory (INEEL) as shown in Figure 1, is operated by Bechtel BWXT Idaho, LLC for the Department of Energy (DOE). The TMI-2 ISFSI was licensed on March 19, 1999 by the Nuclear Regulatory Commission (NRC) pursuant to 10 CFR 72 for authorization to receive, possess, store, and transfer spent fuel and fuel debris, resulting from the 1979 TMI-2 accident, for a twenty-year term. ${ }^{1,2}$

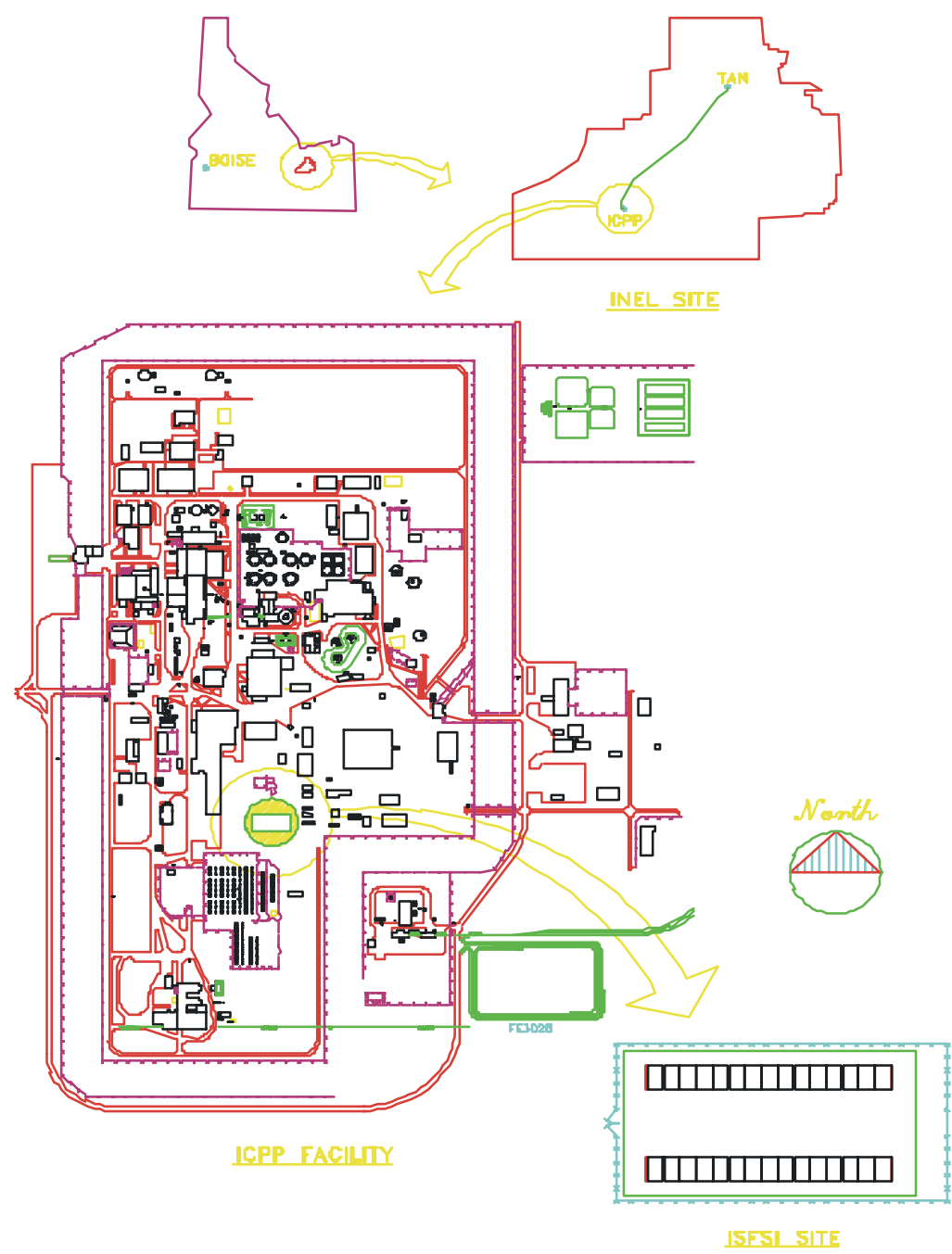

Figure 1. Location of the TMI-2 ISFSI. 
The TMI-2 ISFSI is a modified NUHOMS spent fuel storage system, designated NUHOMS-12T. Each of the thirty NUHOMS-12T modules within the facility provide for the horizontal dry storage of up to twelve TMI-2 stainless steel canisters inside a dry shielded canister (DSC) which is placed inside a concrete horizontal storage module (HSM). The NUHOMS-12T modification includes venting of the DSC through high efficiency particulate air (HEPA) grade filters during storage. The vent system allows for release of hydrogen gas, generated due to radiolysis, and monitoring and/or purging of the system during operation.

The TMI-2 core debris, which had been stored in stainless steel canisters in a fuel pool at the Test Area North (TAN) site within the INEEL, has been transferred to the TMI-2 ISFSI for interim storage. A Settlement Agreement entered into by the State of Idaho, the Department of Energy, and the Department of the Navy in October 1995 established a schedule for commencing core debris transfers by March 31, 1999 , and completing such transfers by June 1, 2001. ${ }^{3}$ The first core debris transfer was completed on March 31, 1999. Nine additional transfers were completed during 2000. The remaining nineteen transfers were completed during 2001, with the last one completed on April 20, 2001. A summary of the TMI-2 core debris storage status is provided in Table 1.

Table 1. TMI-2 Core Debris Storage Status.

DSC/HSM No. Storage Date

$\begin{array}{lll}2 / 16 & \text { March 31, 1999 } & 19 / 12 \\ 3 / 17 & \text { July 10, 2000 } & 12 / 11 \\ 4 / 20 & \text { October 14, 2000 } & 6 / 10 \\ 5 / 22 & \text { October 27, 2000 } & 25 / 9 \\ 11 / 24 & \text { November 6, 2000 } & 20 / 18 \\ 8 / 27 & \text { November 19, 2000 } & 21 / 8 \\ 10 / 28 & \text { November 29, 2000 } & 22 / 7 \\ 9 / 21 & \text { December 7, 2000 } \\ 7 / 26 & \text { December 16, 2000 } & 23 / 6 \\ 13 / 25 & \text { December 21, 2000 } & 24 / 5 \\ 16 / 23 & \text { January 4, 2001 } & 1 / 4 \\ 18 / 19 & \text { January 11, 2001 } & 26 / 3 \\ 14 / 30 & \text { January 19, 2001 } & 27 / 29 \\ 17 / 14 & \text { January 26, 2001 } & 28 / 2 \\ 15 / 13 & \text { February 2, 2001 } & 29 / 1\end{array}$

DSC/HSM No. Storage Date

February 10, 2001

February 15, 2001

February 20, 2001

February 26, 2001

March 5, 2001

March 12, 2001

March 20, 2001

March 27, 2001

March 31, 2001

April 6, 2001

April 9, 2001

April 13, 2001

April 16, 2001

April 20, 2001

A Radiological Environmental Monitoring Program (REMP) was developed for the TMI-2 ISFSI and implemented in accordance with 10 CFR 72.44. This report presents the REMP results during the TMI-2 ISFSI operation in 2001.

\section{PROGRAM DESCRIPTION}

The REMP is designed to monitor the two predominant radiation exposure pathways inherent with the facility design: potential airborne radioactivity releases and direct radiation. The airborne radioactivity release pathway is monitored using a combination of loose surface radioactive 
contamination surveys and periodic airborne radioactivity sampling. The direct radiation exposure pathway is monitored using thermoluminescent dosimetry (TLD) located along the outer perimeter fence of the TMI-2 ISFSI.

Loose surface radioactive contamination surveys are performed at the vent and purge ports of each DSC as well as the drain port of each loaded HSM. The survey frequency is monthly during the first year, quarterly during the second through fifth years, and annually thereafter. The survey frequency for each DSC and loaded HSM begins after DSC insertion into the HSM. The frequency coincides with the radiation monitoring surveillance schedule required by the TMI-2 ISFSI Technical Specifications. ${ }^{4}$ Sample media is analyzed for gross beta radioactivity. Depending on the amount of gross beta radioactivity detected, gamma isotopic analysis is either performed for each sample or for an annual sample composite. The presence of Cs-137 is determined and quantified during the gamma isotopic analysis with a required Lower Limit of Detection (LLD) no greater than $5 \mathrm{nCi}$.

Twenty-two TLD stations are located and maintained along the outer perimeter fence of the TMI2 ISFSI. Four additional TLD stations are maintained outside occupied buildings (CPP-665 and CPP666) within 100 meters of the TMI-2 ISFSI. The TLD station locations are noted in Figure 2. Dosimetry is changed out on a monthly frequency. The minimum detectable dose demonstrated is no greater than 10 mrem.

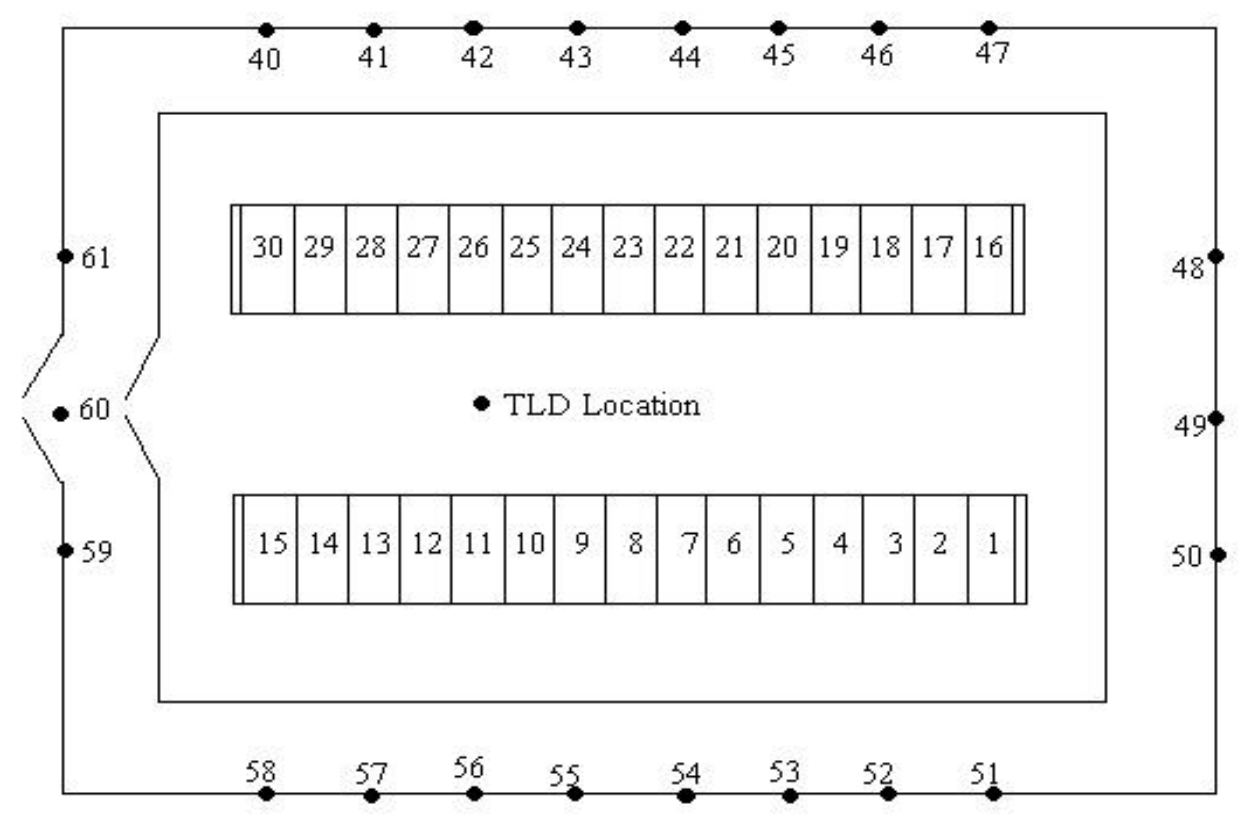

Figure 2. TMI-2 ISFSI TLD Station Locations.

A low-volume air sampler is used to collect a minimum of 5.0E5 liters of air particulate during a seven-day period either during each HSM loading or monthly during periods when no HSM loading operations are occurring. The air sampler is located between the two rows of HSM's inside the TMI-2 ISFSI. Each air particulate sample is analyzed for gross beta radioactivity with an LLD no greater than $0.01 \mathrm{pCi} / \mathrm{m}^{3}$. Depending on the amount of gross beta radioactivity detected, gamma isotopic analysis is either performed for each air particulate sample or for an annual sample composite. The presence of Cs137 is determined and quantified during the gamma isotopic analysis with a required LLD no greater than $0.01 \mathrm{pCi} / \mathrm{m}^{3}$. 


\section{RESULTS}

Nineteen additional shipments of TMI-2 core debris were received and loaded into HSM's during 2001. Contact radiation levels on the front doors, rear panel doors, and end shield walls are measured either within the first twenty-four hours or seven days following the HSM loading, or during monthly or quarterly scheduled surveillances. The highest radiation levels were all less than or equal to $2 \mathrm{mrem} / \mathrm{h}, 5$ $\mathrm{mrem} / \mathrm{h}$, and $1 \mathrm{mrem} / \mathrm{h}$ respectively; well below the respective Technical Specification limits. The highest radiation levels measured on the purge and vent port filter housings during monthly DSC hydrogen gas sampling operations are summarized in Table 2. All loaded HSM's are posted as Radioactive Material Areas. HSM rear panel doors are also posted as Radiation Areas. Neutron radiation detected in HSM's 4 and 22 is attributed to AmBeCm neutron startup sources stored in these locations. ${ }^{5}$

Table 2. Highest Detected Radiation Summary for Loaded HSM's (mrem/h)*.

HSM No. $\quad$ Filter Housing Dose Rate $\quad$ HSM No. $\quad$ Filter Housing Dose Rate

\begin{tabular}{llll}
\hline & & & \\
1 & 35 & 16 & $<1$ \\
2 & 30 & 17 & 50 \\
3 & 21 & 18 & 80 \\
4 & $25^{* *}$ & 19 & 90 \\
5 & 32 & 20 & 120 \\
6 & 37 & 21 & 44 \\
7 & 20 & 22 & $141^{* *}$ \\
8 & 26 & 23 & 15 \\
9 & 35 & 24 & 30 \\
10 & 31 & 25 & 70 \\
11 & 35 & 26 & 40 \\
12 & 60 & 27 & 18 \\
13 & 50 & 28 & 10 \\
14 & 60 & 29 & 15 \\
15 & Empty & 30 & 150 \\
$*$ Includes Compton scatter contribution from inside the HSM. $* *$ Includes 1 to 5 mrem/h neutron.
\end{tabular}

The highest loose surface contamination survey results for the purge, vent, and drain ports are summarized in Table 3. Most analytical gross beta results were less than the Minimum Detectable Activity (MDA) calculated in accordance with NUREG-1507. ${ }^{6}$ Those samples which were characterized as having either positive gross beta or alpha radioactivity were reanalyzed using gamma spectroscopy. There was no Cs-137 or other fission or activation product activity detected.

The gamma isotopic results for the purge, vent, and drain port composite samples from each HSM are summarized in Table 4 in units of radioactivity per sample. Fission product (Cs-137) radioactivity was qualitatively identified in four of eighty-seven composite samples; from the drain ports of HSM's 9, 17, and 20, and the vent port of HSM 10. Comparable levels of radon daughter progeny $(\mathrm{Pb}-$ 214 and Bi-214) were also qualitatively identified. The average MDA of $2 \mathrm{E}-2 \mathrm{nCi} /$ sample was well below the required LLD of $5 \mathrm{nCi} /$ sample. 
Table 3. TMI-2 ISFSI Port Survey Gross Beta/Alpha Results $\left(\mathrm{dpm} / 100 \mathrm{~cm}^{2}\right)$.

\begin{tabular}{cccccc}
\hline HSM No. & Beta & Alpha & HSM No. & Beta & Alpha \\
& & & & & \\
1 & $40^{*}$ & $<19$ & 16 & $<25$ & $<17$ \\
2 & $<24$ & $<18$ & 17 & $<25$ & $<18$ \\
3 & $<24$ & $<18$ & 18 & $27^{*}$ & $<18$ \\
4 & $50^{*}$ & $<18$ & 19 & $90^{*}$ & $<19$ \\
5 & $<23$ & $<18$ & 20 & $<25$ & $<19$ \\
6 & $<23$ & $<18$ & 21 & $<25$ & $33^{*}$ \\
7 & $31^{*}$ & $<18$ & 22 & $36^{*}$ & $<19$ \\
8 & $<24$ & $<18$ & 23 & $79^{*}$ & $<18$ \\
9 & $<24$ & $<18$ & 24 & $31^{*}$ & $<18$ \\
10 & $<24$ & $<18$ & 25 & $<25$ & $<18$ \\
11 & $<24$ & $<19$ & 26 & $<24$ & $<18$ \\
12 & $35^{*}$ & $<18$ & 27 & $<24$ & $16^{*}$ \\
13 & $<25$ & $<18$ & 28 & $28^{*}$ & $<19$ \\
14 & $28^{*}$ & $<19$ & 29 & $62^{*}$ & $<18$ \\
15 & Empty & & 30 & $<24$ & $<18$ \\
* Gamma isotopic results did not indicate the presence of fission or activation product activity. & & & \\
\hline
\end{tabular}

Table 4. TMI-2 ISFSI Purge, Vent, and Drain Port Survey Gamma Isotopic Results (nCi/sample).

\begin{tabular}{|c|c|c|c|c|c|c|c|}
\hline \multirow{2}{*}{$\begin{array}{l}\text { HSM } \\
1\end{array}$} & \multicolumn{3}{|c|}{ Cs-137 Radioactivity } & \multirow{2}{*}{$\begin{array}{c}\text { HSM } \\
16\end{array}$} & \multicolumn{3}{|c|}{ Cs-137 Radioactivity } \\
\hline & $<1.7 \mathrm{E}-2$ & $<1.7 \mathrm{E}-2$ & $<1.6 \mathrm{E}-2$ & & $<1.6 \mathrm{E}-2$ & $<1.8 \mathrm{E}-2$ & $<1.6 \mathrm{E}-2$ \\
\hline 2 & $<1.6 \mathrm{E}-2$ & $<1.7 \mathrm{E}-2$ & $<1.6 \mathrm{E}-2$ & 17 & $<1.7 \mathrm{E}-2$ & $<1.7 \mathrm{E}-2$ & 4.1E-2 \\
\hline 3 & $<1.6 \mathrm{E}-2$ & $<1.7 \mathrm{E}-2$ & $<1.5 \mathrm{E}-2$ & 18 & $<1.6 \mathrm{E}-2$ & $<1.6 \mathrm{E}-2$ & $<1.6 \mathrm{E}-2$ \\
\hline 4 & $<1.6 \mathrm{E}-2$ & $<1.7 \mathrm{E}-2$ & $<1.6 \mathrm{E}-2$ & 19 & $<1.6 \mathrm{E}-2$ & $<1.7 \mathrm{E}-2$ & $<1.6 \mathrm{E}-2$ \\
\hline 5 & $<1.5 \mathrm{E}-2$ & $<1.7 \mathrm{E}-2$ & $<1.5 \mathrm{E}-2$ & 20 & $<1.7 \mathrm{E}-2$ & $<1.6 \mathrm{E}-2$ & $3.2 \mathrm{E}-2$ \\
\hline 6 & $<1.7 \mathrm{E}-2$ & $<1.7 \mathrm{E}-2$ & $<1.6 \mathrm{E}-2$ & 21 & $<1.5 \mathrm{E}-2$ & $<1.9 \mathrm{E}-2$ & $<1.6 \mathrm{E}-2$ \\
\hline 7 & $<1.6 \mathrm{E}-2$ & $<1.5 \mathrm{E}-2$ & $<1.5 \mathrm{E}-2$ & 22 & $<1.6 \mathrm{E}-2$ & $<1.7 \mathrm{E}-2$ & $<2.0 \mathrm{E}-2$ \\
\hline 8 & $<1.8 \mathrm{E}-2$ & $<1.6 \mathrm{E}-2$ & $<1.9 \mathrm{E}-2$ & 23 & $<1.6 \mathrm{E}-2$ & $<1.7 \mathrm{E}-2$ & $<1.5 \mathrm{E}-2$ \\
\hline 9 & $<1.9 \mathrm{E}-2$ & $<1.6 \mathrm{E}-2$ & $2.6 \mathrm{E}-2$ & 24 & $<1.6 \mathrm{E}-2$ & $<1.7 \mathrm{E}-2$ & $<1.9 \mathrm{E}-2$ \\
\hline 10 & $<1.6 \mathrm{E}-2$ & $3.2 \mathrm{E}-2$ & $<1.6 \mathrm{E}-2$ & 25 & $<1.6 \mathrm{E}-2$ & $<1.7 \mathrm{E}-2$ & $<1.6 \mathrm{E}-2$ \\
\hline 11 & $<1.7 \mathrm{E}-2$ & $<1.5 \mathrm{E}-2$ & $<1.6 \mathrm{E}-2$ & 26 & $<1.5 \mathrm{E}-2$ & $<1.5 \mathrm{E}-2$ & $<1.6 \mathrm{E}-2$ \\
\hline 12 & $<1.5 \mathrm{E}-2$ & $<1.1 \mathrm{E}-2$ & $<1.5 \mathrm{E}-2$ & 27 & $<1.6 \mathrm{E}-2$ & $<1.6 \mathrm{E}-2$ & $<1.6 \mathrm{E}-2$ \\
\hline 13 & $<1.6 \mathrm{E}-2$ & $<1.7 \mathrm{E}-2$ & $<1.5 \mathrm{E}-2$ & 28 & $<1.5 \mathrm{E}-2$ & $<1.7 \mathrm{E}-2$ & $<1.7 \mathrm{E}-2$ \\
\hline 14 & $<1.7 \mathrm{E}-2$ & $<1.6 \mathrm{E}-2$ & $<1.6 \mathrm{E}-2$ & 29 & $<1.6 \mathrm{E}-2$ & $<1.7 \mathrm{E}-2$ & $<1.6 \mathrm{E}-2$ \\
\hline 15 & Empty & & & 30 & $<1.8 \mathrm{E}-2$ & $<1.7 \mathrm{E}-2$ & $<1.7 \mathrm{E}-2$ \\
\hline
\end{tabular}

TLD results for the TMI-2 ISFSI are presented in Table 5 in units of mrem/d. Monthly standard deviations were generally less than $0.1 \mathrm{mrem} / \mathrm{d}$. Analysis of variance results indicated monthly variances were different than the pre-operational baseline variance measured in March 1999. T-test results 
indicated monthly mean TLD responses were significantly lower than the pre-operational baseline mean every month due to implementation of a new environmental dosimeter and processing system in June 1999. ${ }^{7}$ It was also noted that mean TLD responses for locations in the south southwest perimeter of the TMI-2 ISFSI were generally the highest with a mean response of $0.7 \mathrm{mrem} / \mathrm{d}$. This is attributed to direct radiation from outdoor mixed waste storage areas in CPP-1617, which are located 200 meters from the TMI-2 ISFSI. All other TLD locations had mean responses of 0.5 to $0.6 \mathrm{mrem} / \mathrm{d}$. The mean response of TLD's located in the two buildings within the 100 meter perimeter of the TMI-2 ISFSI were not significantly different than those at the perimeter fence. However, it was noted that on three separate occasions the TLD response at Location No. 64 was significantly higher than the perimeter fence TLD responses. The relatively higher radiation dose rates at Location No. 64 have been attributed to loaded spent nucle ar fuel shipping cask traffic and staging adjacent to this TLD location unrelated to the TMI-2 ISFSI operations.

Table 5. TMI-2 ISFSI TLD Results (mrem/d).

\begin{tabular}{|c|c|c|c|c|c|c|c|c|c|c|c|c|}
\hline LCTN & JAN & FEB & MAR & APR & MAY & JUN & JUL & AUG & SEP & OCT & $\mathrm{NOV}$ & $\mathrm{DEC}$ \\
\hline 40 & 0.7 & 0.5 & 0.6 & 0.6 & 0.6 & 0.7 & 0.6 & 0.6 & 0.6 & 0.6 & 0.6 & 0.5 \\
\hline 41 & 0.7 & 0.4 & 0.5 & 0.6 & 0.6 & 0.6 & 0.6 & 0.6 & 0.6 & 0.5 & 0.6 & 0.5 \\
\hline 42 & 0.7 & 0.4 & 0.5 & 0.6 & 0.6 & 0.6 & 0.5 & 0.6 & 0.5 & 0.5 & 0.6 & 0.5 \\
\hline 43 & 0.7 & 0.4 & 0.5 & 0.6 & 0.6 & 0.6 & 0.5 & 0.5 & 0.6 & 0.5 & 0.6 & 0.5 \\
\hline 44 & 0.7 & 0.4 & 0.6 & 0.6 & 0.6 & 0.6 & 0.5 & 0.5 & 0.5 & 0.5 & 0.5 & 0.5 \\
\hline 45 & 0.7 & 0.4 & 0.5 & 0.6 & 0.6 & 0.6 & 0.5 & 0.6 & 0.6 & 0.5 & 0.6 & 0.5 \\
\hline 46 & 0.7 & 0.4 & 0.5 & 0.5 & 0.6 & 0.6 & 0.5 & 0.5 & 0.5 & 0.5 & 0.6 & 0.5 \\
\hline 47 & 0.7 & 0.4 & 0.5 & 0.6 & 0.6 & 0.6 & 0.5 & 0.5 & 0.6 & 0.5 & 0.5 & 0.5 \\
\hline 48 & 0.6 & 0.4 & 0.5 & 0.5 & 0.6 & 0.6 & 0.5 & 0.5 & 0.5 & 0.5 & 0.5 & 0.5 \\
\hline 49 & 0.7 & 0.4 & 0.5 & 0.6 & 0.6 & 0.6 & 0.5 & 0.5 & 0.6 & 0.6 & 0.6 & 0.5 \\
\hline 50 & 0.7 & 0.5 & 0.6 & 0.6 & 0.6 & 0.6 & 0.5 & 0.6 & 0.6 & 0.5 & 0.6 & 0.5 \\
\hline 51 & 0.8 & 0.5 & 0.6 & 0.6 & 0.7 & 0.7 & 0.6 & 0.6 & 0.6 & 0.6 & 0.6 & 0.6 \\
\hline 52 & 0.8 & 0.5 & 0.6 & 0.6 & 0.7 & 0.7 & 0.6 & 0.7 & 0.6 & 0.6 & 0.6 & 0.6 \\
\hline 53 & 0.8 & 0.5 & 0.6 & 0.7 & 0.7 & 0.7 & 0.6 & 0.7 & 0.7 & 0.6 & 0.6 & 0.6 \\
\hline 54 & 0.8 & 0.6 & 0.6 & 0.7 & 0.8 & 0.7 & 0.6 & 0.7 & 0.7 & 0.6 & 0.6 & 0.6 \\
\hline 55 & 0.8 & 0.6 & 0.6 & 0.7 & 0.7 & 0.8 & 0.6 & 0.7 & 0.7 & 0.6 & 0.8 & 0.6 \\
\hline 56 & 0.9 & 0.6 & 0.7 & 0.7 & 0.8 & 0.8 & 0.7 & 0.7 & 0.7 & 0.7 & 0.7 & 0.6 \\
\hline 57 & 0.9 & 0.6 & 0.7 & 0.7 & 0.8 & 0.8 & 0.7 & 0.7 & 0.7 & 0.7 & 0.7 & 0.7 \\
\hline 58 & 0.9 & 0.6 & 0.7 & 0.7 & 0.8 & 0.8 & 0.7 & 0.7 & 0.7 & 0.7 & 0.7 & 0.7 \\
\hline 59 & 0.9 & 0.6 & 0.7 & 0.7 & 0.7 & 0.8 & 0.6 & 0.7 & 0.7 & 0.6 & 0.7 & 0.6 \\
\hline 60 & 0.8 & 0.5 & 0.6 & 0.6 & 0.7 & 0.7 & 0.6 & 0.6 & 0.6 & 0.6 & 0.6 & 0.6 \\
\hline 61 & 0.8 & 0.5 & 0.6 & 0.6 & 0.7 & 0.7 & 0.6 & 0.6 & 0.6 & 0.6 & 0.6 & 0.6 \\
\hline Mean & 0.8 & 0.5 & 0.6 & 0.6 & 0.7 & 0.7 & 0.6 & 0.6 & 0.6 & 0.6 & 0.6 & 0.6 \\
\hline 62 & 0.6 & 0.4 & 0.4 & 0.4 & 0.5 & 0.5 & 0.4 & 0.5 & 0.4 & 0.4 & 0.4 & 0.4 \\
\hline 63 & 0.6 & 0.4 & 0.4 & 0.4 & 0.5 & 0.5 & 0.4 & 0.5 & 0.5 & 0.4 & 0.4 & 0.5 \\
\hline 64 & 1.3 & 0.5 & 0.6 & 0.6 & 0.6 & 0.6 & 0.5 & 0.6 & 0.5 & 0.5 & 0.9 & 1.2 \\
\hline 65 & 0.8 & 0.5 & 0.6 & 0.5 & 0.6 & 0.6 & 0.5 & 0.6 & 0.5 & 0.5 & 0.5 & 0.5 \\
\hline Mean & 0.8 & 0.4 & 0.5 & 0.5 & 0.6 & 0.6 & 0.4 & 0.6 & 0.5 & 0.4 & 0.6 & 0.6 \\
\hline
\end{tabular}

Air sampling gross beta radioactivity results for the TMI-2 ISFSI are presented in Table 6. Air samples were collected during the weeks that HSM's were loaded in January, February, March, and April. Air samples were collected once a month during the remainder of the year. Gamma spectroscopy results of the composited air samples indicated the presence of radon daughter progeny (Pb-214, Tl-204, and Bi214), but no fission or activation product activity. The required LLD of $0.01 \mathrm{pCi} / \mathrm{m}^{3}$ for Cs- 137 was demonstrated with a calculated MDA of $17.3 \mathrm{pCi} / \mathrm{sample}$ for the analytical system, and a composite air sample volume of $1.3 \mathrm{E} 4 \mathrm{~m}^{3}$, hence $1 \mathrm{E}-3 \mathrm{pCi} / \mathrm{m}^{3}$. 
Table 6. TMI-2 ISFSI Air Sample Results (pCi $\left./ \mathrm{m}^{3}\right)$.

\begin{tabular}{ll}
\hline Sample Date & Gross Beta \\
& \\
\hline & \\
January & $0.03,0.02,0.03,0.02$ \\
February & $0.02,0.02,0.02,0.01$ \\
March & $0.02,0.01,0.01,0.01$ \\
April & $0.01,0.02,0.01,0.02$ \\
May & 0.01 \\
June & 0.01 \\
July & 0.02 \\
August & 0.02 \\
September & 0.03 \\
October & 0.01 \\
November & 0.02 \\
December & 0.03 \\
& \\
\hline
\end{tabular}

\section{DISCUSSION}

The TMI-2 ISFSI REMP was conducted in accordance with established procedures. Sample media for three port contamination surveys (December HSM 7, February HSM 16, and February HSM 17) could not be accounted for after gross beta analyses were completed, but before sample compositing for gamma spectroscopy analysis could be performed. The absence of detected gross beta activity in these samples, and the $99 \%$ recovery of the remaining contamination survey samples, indicate the loss of monitoring data does not impact the estimation of the potential dose commitment to the general public. There were no changes in sampling locations during the monitoring period. There were no deviations from the established sampling schedule.

Review of the gross beta radioactivity results for HSM's 9, 10, 17, and 20 (all less than MDA) and vent port radiation survey results for HSM 10 (stable trend) neither indicate a build up of radioactivity in the vent port HEPA filter, nor a breach of DSC containment. The relatively low loose surface Cs-137 radioactivity is attributed to the resuspension of radioactivity during range fires and dust storms. The loose surface radioactive contamination surveying and airborne radioactivity sampling results indicate there has been no measurable release of radioactive material from the DSC's stored in the HSM's at the ISFSI above and beyond that projected in the Final Environmental Impact Statement (EIS) and summarized in Table $7 .{ }^{8}$ Radioanalytical results are not significantly different from pre-operational results as well as those projected in the EIS.

The radiation dosimetry results indicate there has been no measurable increase in ambient background radiation levels outside the TMI-2 ISFSI perimeter fence attributed to storage of the TMI-2 core debris, however the results do indicate an influence from an outdoor mixed waste storage facility adjacent to the ISFSI. The absence of any significant increase in radiation levels outside the TMI-2 ISFSI perimeter fence is also supported by conclusions reached in the EIS. 
Table 7. Postulated Airborne Radioactive Material Release During Normal Operations (Ci/y).

\begin{tabular}{llllll}
\hline Radionuclide & Release & Radionuclide & Release & Radionuclide & Release \\
& & & & & \\
\hline Cs-137 & $1.4 \mathrm{E}-3$ & Am-241 & $4.1 \mathrm{E}-5$ & $\mathrm{H}-3$ & $1.5 \mathrm{E}+3$ \\
$\mathrm{Ba}-137 \mathrm{~m}$ & $1.4 \mathrm{E}-3$ & $\mathrm{Co}-60$ & $2.8 \mathrm{E}-5$ & $\mathrm{Eu}-155$ & $6.1 \mathrm{E}-6$ \\
$\mathrm{Y}-90$ & $1.2 \mathrm{E}-3$ & $\mathrm{Pu}-239$ & $2.2 \mathrm{E}-5$ & $\mathrm{Pu}-238$ & $5.8 \mathrm{E}-6$ \\
$\mathrm{Sr}-90$ & $1.2 \mathrm{E}-3$ & $\mathrm{Sm}-151$ & $1.8 \mathrm{E}-5$ & $\mathrm{Sb}-125$ & $3.8 \mathrm{E}-6$ \\
$\mathrm{Pu}-241$ & $8.2 \mathrm{E}-4$ & $\mathrm{Pu}-240$ & $1.2 \mathrm{E}-5$ & $\mathrm{Cs}-134$ & $1.6 \mathrm{E}-6$ \\
$\mathrm{Kr}-85$ & $1.3 \mathrm{E}+4$ & $\mathrm{Ni}-63$ & $1.1 \mathrm{E}-5$ & $\mathrm{I}-129$ & $6.4 \mathrm{E}-10$ \\
$\mathrm{Pm}-147$ & $5.0 \mathrm{E}-5$ & $\mathrm{Eu}-154$ & $8.4 \mathrm{E}-6$ & & \\
\hline
\end{tabular}

Calibration and quality control of instrumentation used for gross beta analysis of surface contamination and airborne radioactivity sample media is maintained in accordance with procedures used by the INEEL Radiological Control Program. ${ }^{9}$ Radioactive sources used for instrumentation calibration and quality control are traceable to the National Institute of Standards and Technology (NIST). The radioanalytical program does not participate in either an intracomparison or intercomparison program.

The dosimetry processor participated in the twelfth environmental dosimetry intercomparison program conducted by the DOE Environmental Measurements Laboratory (EML) during 2000, but intercomparison results have not yet been published by EML.

The radioanalytical laboratory that provides gamma spectroscopy services for composite sample analysis participated in a regularly scheduled intercomparison program conducted by the EML. The intercomparison results for the sample geometry used for composite samples of surface contamination survey and air sample media conducted during 2001 are published. ${ }^{10,11}$ The results are summarized in Table 8. A description of the evaluation criteria can be found at the EML website (www.eml.doe.gov). The evaluation results for Cs-137 identification indicate the INEEL was conservative in their reporting by about $5 \%$.

Table 8. Gamma Spectroscopy Intercomparison Results for June and December 2001 (Bq/filter).

Radionuclide INEEL Value (Error) EML Value (Error) INEEL/EML Evaluation

$\begin{array}{lllll}\text { Co-60 } & 20.100(1.500) & 19.440(0.500) & 1.034 & \text { Acceptable } \\ \text { Cs-137 } & 9.230(1.000) & 8.760(0.340) & 1.054 & \begin{array}{c}\text { Acceptable } \\ \text { Acceptable }\end{array} \\ \text { Mn-54 } & 6.990(0.800) & 6.520(0.280) & 1.072 & \\ & & & & \\ \text { Co-60 } & 17.700(1.700) & 17.500(0.470) & 1.011 & \text { Acceptable } \\ \text { Cs-134 } & 13.200(2.100) & 12.950(0.362) & 1.019 & \text { Acceptable } \\ \text { Cs-137 } & 17.900(1.500) & 17.100(0.580) & 1.047 & \text { Acceptable } \\ \text { Mn-54 } & 85.200(5.800) & 81.150(4.760) & 1.050 & \text { Acceptable }\end{array}$

It can be concluded from the results of the TMI-2 ISFSI REMP that airborne radioactivity releases and direct radiation exposure from the facility during 2001 did not contribute to any increase in 
the estimate of maximum potential dose commitment to the general public. There were no radioactive liquid effluents released from the facility, hence no radionuclides to report. The effective dose equivalent to the Maximum Exposed Individual reported in the EIS is $2.7 \mathrm{E}-3 \mathrm{mrem} / \mathrm{y}$.

\section{REFERENCES}

1. Issuance of Materials License SNM-2508 for the Three Mile Island, Unit 2, Independent Spent Fuel Storage Installation (TAC No's L22283 and L22800), March 19, 1999, Docket No. 72-20.

2. 10 CFR 72, "Licensing Requirements for the Independent Storage of Spent Nuclear Fuel and High-Level Radioactive Waste", Code of Federal Regulations, Office of the Federal Register, August 1988.

3. Settlement Agreement between the State of Idaho, Department of the Navy, and the Department of Energy, October 16, 1995.

4. Technical Specifications and Bases for the INEEL TMI-2 Independent Spent Fuel Storage Installation, Current issue.

5. G. G. Hall, Impact of AmBeCm Sources on the TMI-2 ISFSI Design Basis, Engineering Design File 1793, Revision 4, March 15, 2001.

6. $\quad$ NUREG/CR-1507, "Minimum Detectable Concentrations with Typical Radiation Survey Instruments for Various Contaminants and Field Conditions”, December 1997.

7. P. E. Ruhter, New Environmental Dosimeter Response, letter PER-17-99, July 29, 1999.

8. NUREG-1626, "Final Environmental Impact Statement for the Construction and Operation of an Independent Spent Fuel Storage Installation to Store the Three Mile Island Unit 2 Spent Fuel at the Idaho National Engineering and Environmental Laboratory", Docket No. 72-20, March 1998.

9. INEEL, Radiological Control Manuals $15 B$ and 15C, Current issues.

10. EML-613, "Semi-Annual Report of the Department of Energy, Office of Environmental Management, Quality Assessment Program", June 2001.

11. EML-615, "Semi-Annual Report of the Department of Energy, Office of Environmental Management, Quality Assessment Program", December 2001. 